\title{
ANALISIS KESALAHAN BERBAHASA INDONESIA PADA STATUS DAN KOMENTAR DI FACEBOOK
}

\author{
Kodrat Eko Putro Setiawan, Wixke Zyuliantina \\ kodratekoputrosetiawan08@gmail.com , wixkezyt@gmail.com, \\ Universitas PGRI Madiun
}

*Diterima: 12 Juli 2020, Disetujui: 06 Agustus 2020

\begin{abstract}
Language errors are often found in status and comments on Facebook users. The method in this research is descriptive qualitative. The data in this study are in the form of words. This study aims to describe Indonesian language errors in the form of spelling in status and comments on Facebook. Data collection techniques in this study use consider and record. Analysis of the data in this study by classifying and classifying. The results of this study are language errors in the status and comments in the facebook include making acronyms, using italics, using capital letters, using vocabulary, making abbreviations, composing sentences, writing terms, writing question marks, using dots, using exclamation points, using signs commas, use of quotation marks and price writing. Besides, other language errors in the form of variations of slang include: Indonesian slang mixed with English; Indonesian slang, English, and Javanese; Indonesian slang, English, and Mandarin.

Keywords: Language Error, Status, Comments, Facebook.
\end{abstract}

\begin{abstract}
Abstrak
Kesalahan Berbahasa sering ditemukan dalam status dan komentar pada pengguna Facebook. Metode yang digunakan dalam penelitian ini adalah deskriptif kualitatif. Data dalam penelitian berupa kata-kata. Penelitian ini bertujuan untuk mendeskripsikan kesalahan-kesalahan dalam berbahasa Indonesia berupa ejaan dalam status dan komentar di facebook. Teknik yang digunakan untuk pengumpulan data dalam penelitian ini adalah simak dan catat. Analisis data dengan cara mengklasifikasi dan mengelompokkan. Hasil penelitian ini adalah kesalahan dalam berbahasa pada status dan komentar dalam Facebook meliputi pembuatan akronim, penggunaan huruf miring, penggunaan huruf kapital, penggunaan kosakata, pembuatan singkatan, penyusunan kalimat, penulisan istilah, penulisan tanda tanya, penggunaan pada tanda titik, penggunaan pada tanda seru, penggunaan pada tanda koma, penggunaan pada tanda petik dan penulisan harga. Selain itu, kesalahan berbahasa lainnya berupa variasi dalam bahasa gaul meliputi: bahasa Indonesia gaul yang bercampur dengan bahasa Inggris;bahasa Indonesia gaul,bahasa Inggris, dan bahasa Jawa; bahasa Indonesia gaul, bahasa Inggris dan bahasa Mandarin.

Kata Kunci: Kesalahan Berbahasa,Status, Komentar, Facebook.
\end{abstract}

\section{PENDAHULUAN}

Informasi sekarang telah berkembang secara pesat, salah satu di antaranya adalah melalui media sosial. Media sosial kini telah maju. Hal itu disebabkan oleh adanya perkembangan teknologi informasi, terutama internet. Berpijak dari data kompas.com bulan Februari 2020, dapat diketahui saat ini orang yang menggunakan internet di Indonesia adalah 175,4 juta dengan pergerakan 64 persen. Maknanya, jumlah keseluruhan sebesar 272 juta orang di Indonesia, pada pergerakan 64 persen 
sudah terhubung segala hal yang berkaitan dengan daring. Rata-rata orang Indonesia berselancar di internet selama 4 jam 46 menit setiap harinya. Sebagian besar mengakses sosial media. Tercatat pemakai aktif sosial media di Indonesia adalah 160 juta dengan pergerakan 59 persen. Bisa diambil rata-rata masyarakat Indonesia menggunakan waktu selama 3 jam 4 menit untuk menggunakan sosial medianya (kompas.com).

Manusia merupakan bagian dari budaya. Sebagai bagian dari budaya, tentunya perlu untuk melakukan interaksi dengan manusia lainnya. Pada kenyataannya, dalam melakukan interaksi membutuhkan norma dan etika supaya hubungan satu dengan lainnya berjalan dengan baik, tidak ada yang merasa ada gangguan dan tidak muncul masalah (Markhamah, 2014:1). Suatu suku di sebuah bangsa pasti mempunyai peraturan, norma-norma, dan etika dalam berinteraksi satu dengan yang lainnya dan termasuk etika berbahasa. Hal itu berlaku secara umum, termasuk suku Jawa, Sunda, Minangkabau, atau suku lainnya.

Manusia merupakan makhluk ciptaan Allah yang paling mulia daripada makhluk manapun di dunia ini. Meskipun demikan, adanya kemajuan teknologi dan industri melahirkan budaya teknokrasi dan memiliki pengaruh yang luas menjadikan manusia kurang yakin terhadap jatidirinya. Manusia yang menjadi ciptaan paling mulia tadi bertransformasi menjadi hamba dari teknologi, menjadi kaum konsumeris, dan semua tentang harga dirinya dikaitkan pada hal-hal yang bersifat materi.

Bahasa mejadi media komunikasi antarsesama masyarakat. Bahasa menjadi sebuah lambang bunyi yang bersifat arbitrer, difungsikan oleh para anggota masyarakat untuk menjalin kerja sama, interaksi sosial, dan mengidentifikasi diri (Kridalaksana, 2001:21). Arbitrer artinya manasuka, dalam konteks ini ialah manasuka dalam menentukan lambang yang dipakai untuk berkomunikasi dan berinteraksi. Sebagai alat komunikasi, bahasa dituntut mempunyai fungsi komunikatif.

Agar dapat memenuhi syarat sebagai fungsi komunikatif, bahasa hendaknya digunakan dengan sebaik-baiknya supaya tidak memunculkan makna ganda atau kesalahan yang membuat orang lain tidak paham dengan bahasa yang dipakai.Akan tetapi, pengguna bahasa terkadang tidak dapat memenuhi hal itu dengan baik. Secara sengaja atau tidak sering kali pemakaian bahasanya ternyata keliru, bahkan salah.

Pada era ini, media sosial telah maju dengan sangat pesat. Hal itu dibuktikan dengan adanya perkembangan teknologi yang semakin cepat, terutama internet yang bisa digunakan untuk media apapun, termasuk handphone yang merupakan bagian dari hal yang sangat pribadi. Di balik perkembangan yang sangat pesat terkait media sosial itu ternyata ada hal yang menarik untuk dianalisis. Hal tersebut adalah penggunaan bahasa, khususnya bahasa Indonesia. Bahasa Indonesia yang digunakan di media sosial berkembang dan mempunyai ciri khas tersendiri. Salah satu jenis media sosial yang menarik dianalisis terkait kesalahan berbahasa penggunanya adalah Facebook.

Facebook adalah media sosial yang populer saat ini. Sebagai media sosial, Facebook menjadi media yang digunakan untuk berkomunikasi. Media sosial tersebut memberikan berbagai kemudahan dalam melakukan komunikasi. Facebook memberikan manfaat dalam menjalin komunikasi dengan berbagai kalangan. Fitur yang disediakan Facebook untuk berkomunikasi adalah perbaruan status. Perbaruan status menjadi salah satu fitur yang bisa digunakan dengan aktivitas yang sedang dilakukan. Ketika status sudah berhasil posting, orang lain yang berteman bisa dengan mudah memberikan komentar pada status yang dibuat. Dari hal tersebut 
terjadilah komunikasi melalui Facebook, dengan bahasa tulis yang digunakan sebagai media komunikasi.

Pada bagian status dan komentar di Facebook pengguna biasanya menuliskan apa yang diinginkan dan mengungkapkan sesuai yang dikehendakinya. Adanya kebebasan tersebut dimiliki pengguna dalam memilih dan memakai bahasa dalam menyampaikan suatu pesan. Kebebasan mengungkapkan ekspresi khususnya dalam menggunakan bahasa untuk menulis status dan komentar terkadang sulit dipahami pembaca, hal itulah yang membuat banyaknya terjadi kesalahan berbahasa pada status dan komentar yang dibuat pengguna Facebook.

Pada status dan komentar banyak menampilkan pesan yang ditulis menggunakan bahasa yang cukup bervariasi. Ada berupa penyingkatan kata, pilihan kata yang bermacam-macam dapat membuat komentar lebih komunikatif dan menarik. Hingga tulisan komentar dalam Facebook banyak ditemukan kesalahan berupa ejaan. Hal itu disebabkan karena penggunaan bahasa yang variatif. Pembuatnya kurang memahami kaidah berbahasa yang benar sehingga dibiarkan begitu saja.

Tujuan dari penulisan artikel ini agar para pengguna facebook memahami bahwa dalam sebuah penulisan yang intinya termuat dalam ranah informasi publik baiknya menggunakan kaidah bahasa yang baik, agar maksud dan tujuan bisa tersampaikan dengan baik pula. Sebagai warga Negara yang baik untuk terus melestarikan bahasa Indonesia yang telah disepakati sebagai bahasa resmi dengan mematuhi kaidah yang telah ada.

\section{KAJIAN LITERATUR}

Dahulu pembelajaran bahasa Indonesia menitikberatkan pada masalah struktur dan kaidah bahasa. Kini pembelajaran bahasa Indonesia lebih mengarah pada paradigma komunikatif. Walaupun demikian, baiknya juga tetap memperhatikan struktur dan sesuai kaidah bahasa Indonesia. Hal ini penting sebab bahasa Indonesia mempunyai berbagai fungsi pada kehidupan. Andayani (2015:1) menjelaskan bahwa bahasa Indonesia mempunyai berbagai fungsi dalam kehidupan masyarakat Indonesia. Bahasa Indonesia mempunyai nilai sejarah, nilai politik, nilai sosiologi, dan nilai keindahan yang erat kaitannya dengan eksistensi bangsa Indonesia.

Pada perkembangannya, masih banyak ditemukan kesalahan dalam berbahasa Indonesia. Setyawati (2013:11) menjelaskan bahwa bahasa Indonesia ada kata-kata yang mengandung sebuah kesalahan, kata-kata tersebut antara lain: salah, penyimpangan, pelanggaran, dan kekhilafan. Kata "salah" artinya sesuatu yang dilakukan tidak benar, tidak sesuai norma, tidak sesuai aturan. Penyebabnya karena pengguna bahasa belum mengetahui. Kata "penyimpangan" artinya menyimpang tidak sesuai norma yang ada. Pengguna bahasa melakukan penyimpangan karena beberapa hal, yakni ketidakmauan, adanya rasa enggan, rasa malas untuk mengikuti norma yang telah ada. Sebetulnya pengguna bahasa mengetahui norma-norma yang benar, namun yang dipakai adalah norma lain sesuai dengan keinginannya sendiri. Penyebab lain penyimpangan ialah keinginan kuat yang tidak bisa dihindari. Sikap dalam berbahasa inilah yang bisa membentuk suatu kata, sebuah istilah, slang, jargon, dan prokem. Kata "pelanggaran" berarti pengguna bahasa dengan rasa penuh kesadaran tidak mau mengikuti norma yang telah ada, meskipun telah mengerti bahwa yang dilakukan dapat berakibat tidak baik. Kata "kekhilafan" yakni suatu proses berkaitan dengan faktor psikologis, dalam hal ini

Tabasa: Jurnal Bahasa, Sastra, dan Pengajarannya

Vol. 1, No. 1, Juni 2020 
seseorang dapat khilaf menerapkan suatu teori atau norma bahasa, khilaf berakibat sikap yang keliru memakai. Oleh sebab itu, kekhilafan bisa diartikan kekeliruan.

Kajian kesalahan dalam berbahasa merupakan teknik untuk mengidentifikasi, mengelompokkan, menafsir secara sistematik, kesalahan yang dilakukan pengguna bahasa ketika mempelajari sebuah bahasa asing atau mempelajari bahasa kedua dengan memakai teori dan langkah-langkah linguistik (Markhamah, 2014:45). Dalam menemukan kesalahan berbahasa, instrumen yang bisa digunakan adalah keberterimaan suatu bahasa oleh penggunanya atau sesuai pemilik asli bahasa yang berkaitan. Artinya, bila seseorang sedang mempelajari bahasa Indonesia, misalnya suatu kalimat atau kata yang dilafalkan oleh pengguna bahasa tadi bisa dikatakan salah jika suatu kalimat atau kata yang digunakan tidak memenuhi kaidah yang ada dalam bahasa Indonesia.

Kajian kesalahan berbahasa memiliki ruang lingkup yang tidak jauh berbeda dengan linguistik. Hal tersebut berkaitan dengan ilmu yang menjadi dasar dalam menganalisis kesalahan berbahasa, antara lain: fonologi, morfologi, sintaksis, dan semantik. Oleh sebab itu, ruang lingkup kesalahan berbahasa meliputi tataran fonologi, morfologi, sintaksis, dan semantik.

Kesalahan pada bidang fonologi, fonologi merupakan cabang ilmu bahasa yang membahas tentang fonem. Fonologi menjadi bidang yang menyelidiki bunyi bahasa menurut fungsinya (Alwi, dkk., 2007:320). Berkaitan dengan bidang tersebut, kesalahan pada fonologi berkaitan dengan penggunaan pelafalan dan ejaan. Kesalahan yang di maksud dalam hal ini antara lain terkait dengan sebuah pelafalan dan penulisan bunyi suatu bahasa. Hal itu sejalan dengan Pateda (1989:50) mengungkapkan bahwa kesalahan pada daerah fonologi merupakan kesalahan yang selalu berbicara tentang pelafalan dan penulisan bunyi bahasa.

Ketidaktepatan dalam melafalkan fonem-fonem yang diadopsi dari bahasa lain masuk dalam kesalahan fonologi. Kesalahan itu di antaranya, pengucapan fonem dari bahasa Arab, Inggris, dan lain-lain, yang dalam bahasa Indonesia fonem-fonem itu tidak ada. Kesalahan yang di maksud misalnya kesalahan ucapan kata vak menjadi pak, insyaf menjadi insaf, syarat menjadi sarat, syah menjadi sah. Wujud kesalahan bidang fonologi lainnya yakni kesalahan pada pemakaian ejaan, contohnya, dalam penulisan huruf kapital, huruf miring, tanda baca, penulisan sebuah lambang bilangan, dan lainnya.

Kesalahan berikutnya ialah bidang morfologi. Kesalahan bidang ini berhubungan dengan suatu tata bentuk kata. Dalam hal ini khususnya, bahasa Indonesia, kesalahan bidang morfologi berkaitan dengan derivasi, pilihan kata, kontaminasi, dan pleonasme (Pateda, 1989:53). Kesalahan yang ada hubungannya dengan derivasi yakni kesalahan yang ada kaitannya dengan afiksasi, pengulangan, dan komposisi. Kesalahan yang ada hubungan dengan afiksasi meliputi penambahan prefiks, infiks, sufiks, atau konfiks. Kesalahan yang berhubungan dengan reduplikasi di antaranya penulisan kata ulang. Kesalahan yang berhubungan dengan komposisi contohnya kesalahan dalam penulisan gabungan kata.

Kesalahan yang berkaitan dengan derivasi, khususnya kata yang mengandung sisipan lebih sering terjadi. Hal ini disebabkan kata-kata yang mendapatkan sisipan dalam bahasa Indonesia jumlahya terbatas. Di sisi lain terdapat kata-kata yang secara sepintas seperti mengandung sisipan -el-, -er-, atau $-e m-$.

Kesalahan lain terkait derivasi, misalnya penggunaan imbuhan di antaranya penggunaan kata-kata seperti lantik, jumpa, menyolok, mentargetkan, dikontrakan, menghimbau dan lainnya dalam suatu kalimat. Kata lantik dan jumpa seharusnya 
mendapatkan imbuhan meN- dan ber-, menjadi kata melantik dan berjumpa. Kesalahan penggunaan kata menyolok dan mentargetkan berhubungan dengan kaidah morfologis pembentukan kata dengan prefiks meN-. Jadi, kata yang betul adalah mencolok. Sebaliknya, kata dasar dalam bahasa Indonesia yang diawali konsonan /k/, /p/, /t/, /s/, yang mendapatkan prefiks meN-,konsonan awal pada kata dasar tersebut akan luluh. Jadi kata yang benar adalah menargetkan.

Berbeda kasusnya dengan kata dikontrakan dan menghimbau. Kata tersebut dibentuk dari kata dasar kontrakmendapat afiks kombinasi di-kan, bukan mendapatkan imbuhan kombinasi di-an. Dalam bahasa Indonesia tidak ada imbuhan kombinasi di-an. Jadi, kata yang benar adalah dikontrakkan. Kata menghimbau kurang tepat, karena bentuk dasar harusnya imbau bukan himbau.

Kata imbau mendapatkan imbuhan meN- menjadi mengimbau.

Kesalahan pembentukan yang terkait dengan reduplikasi di antaranya kesalahan dalam penulisan kata ulang atau penggunaan bentuk ulang bersamaan dengan kata-kata yang menyatakan jumlah jamak. Misalnya, para mahasiswamahasiswa, semua pegawai-pegawai, banyak warga-warga, dan lainnya. Seharusnya cukup ditulis para mahasiswa, semua pegawai, dan banyak warga.

Kesalahan bidang sintaksis ialah kesalahan struktur frase, kalimat, serta ketidaktepatan pemakaian suatu partikel. Analisis tentang kesalahan dalam bidang susunan kalimat menyangkut urutan dari kata, adanya kepaduan, susunan dalam frase, kepaduan antar kalimat, dan logika dalam kalimat. Ketika berbahasa, orang melafalkan suatu kalimat yang digunakan untuk menyatakan sebuah pikiran, gagasan atau perasaan.

Supaya dapat berbahasa dengan baik, hendaknya harus bisa menyusun suatu kalimat dengan baik, memahami kaidah tata dalam kalimat (sintaksis). Hal tersebut perlu dilakukan karena tata kalimat berada pada posisi yang penting dalam pengetahuan tentang bahasa, perwujudan berbahasa seseorang dominan dinyatakan dalam kalimat, walaupun kalimat, klausa, frase, dan kata itu berunsurkan fonem atau bunyi.

Kesalahan pada bidang sintaksis mempunyai hubungan yang erat dengan kesalahan pada bidang morfologi. Hal itu disebabkan karena kalimat terdiri dari unsur kata-kata. Namun, kesalahan bidang sintaksis berbeda dengan kesalahan bidang morfologi. Perbedaan kesalahan kedua bidang itu adalah sebagai berikut. Kesalahan pada bidang morfologi yakni kesalahan yang terkait dengan bentuk kata, dapat diketahui bahwa suatu bentuk kata itu salah, tanpa mengganggu bentuk itu dipakai dalam suatu kalimat. Contohnya, kata-kata lantik, jumpa, menyolok, mentargetkan, dikontrakan, dipelajarkan, mengenyampingkan, dan lainnya. Katakata tersebut secara morfologis salah karena tidak sesuai kaidah pembentukan kata dalam bahasa Indonesia.

Kesalahan bidang semantik. Kesalahan pada bidang ini berkaitan dengan pemahaman makna kata dan ketepatannya dalam pemakaian sebuah kata ketika bertutur atau menulis sebuah kalimat. Kesalahan ini terkait bidang semantik. Semantik merupakan cabang ilmu bahasa yang mengkaji mengenai makna pada pemakaian bahasa. Selain itu, semantik juga membahas tentang makna sebuah kata dan kalimat; pengetahuan mengenai asal-usul dan pergeseran makna sebuah kata; bagian struktur dari bahasa yang berkaitan dengan makna dari suatu ungkapan atau struktur makna dalam suatu wicara (Alwi, dkk. (ed.), 2007:1025).

Pemahaman makna kata merupakan syarat yang harus dipenuhi oleh pemakai bahasa. Sementara itu, permasalahan makna adalah permasalahan yang bersifat abstrak, yang rumit untuk dikaji. Penyebabnya ialah makna berhubungan

Tabasa: Jurnal Bahasa, Sastra, dan Pengajarannya

Vol. 1, No. 1, Juni 2020 
dengan bayangan dan imajinasi pemakai bahasa mengenai sesuatu. Sesuatu yang dimaksud dapat berkaitan dengan benda, perasaan, peristiwa, proses, atau abstraksi sesuatu.

Macam-macam kesalahan berbahasa meliputi kesalahan acuan atau (referential errors); Kesalahan register atau (register errors); Kesalahan sosial atau (sosial errors); Kesalahan tekstual atau (textual errors); Kesalahan penerimaan atau (reseptive errors); Kesalahan pengungkapan atau (ekspressive errors); Kesalahan perorangan atau (errors of individuals); Kesalahan kelompok atau (errors of groups); Kesalahan menganalogi atau (errors of overgeneralization atau analogical errors); Kesalahan transfer atau (transfer errors); Kesalahan guru; Kesalahan lokal atau (local errors); dan Kesalahan global (Markhamah, 2014:51).

Kesalahan acuan atau disebut referential errors berhubungan dengan realisasi suatu benda, sebuah proses, atau suatu peristiwa yang tidak sesuai dengan acuan keinginan dari pembicara atau penulis. Contoh : Pergilah kau ke pasar, belilah bawang putih. Namun kenyataannya yang dibeli bawang merah.Kesalahan register atau disebut register errors merupakan kesalahan yang berhubungan dengan sebuah pekerjaan. Contoh : Dokter mengatakan, "operasi tumor pak Agus berjalan lancar kemarin". Bagi kepolisian kata "operasi" biasanya dihubungkan dengan pemeriksaan surat kendaraan bermotor, berbeda dengan dokter, "operasi" berhubungan dengan membedah tubuh untuk penyelamatan. Kesalahan sosial atau disebut sosial errors yakni kesalahan dalam memilih kata yang diakibatkan pemakai bahasa lupa memperhatikan status sosial orang yang menjadi lawan bicara. Contoh : Kepala Kampung Kauman mampus kemarin. Kesalahan tekstual (textual errors) : kesalahan berbahasa yang disebakan oleh tafsiran yang keliru terhadap kalimat atau wacana yang didengar atau dibaca. Contoh : Anak dokter Ahmad Ali sakit. Hendaknya redaksi teksnya diperbaiki menjadi, "Anak dokter yang bernama Ahmad Ali sakit", "Anak dokter, Ahmad Ali, sakit", dan "Dokter Ahmad, Ali anaknya sakit".

Kesalahan penerimaan disebut reseptive errors merupakan kesalahan yang disebabkan oleh keterampilan menyimak atau membaca yang kurang baik. Kaitannya dengan keterampilan menyimak yakni pendengar kurang mencermati pesan yang telah disampaikan pembicara, media dengar pendengar yang kurang berfungsi dengan baik, suasana hati dari pendengar kurang mendukung, lingkungan dari pendengar kurang baik, ujaran yang telah disampaikan tidak jelas, pemilihan kata atau kalimat yang digunakan oleh pembicara bermakna ganda, pesan yang disampaikan banyak sehingga hal itu membuat sulit untuk diingat oleh pendengar. Contoh : seorang kakak menyuruh adiknya ke pasar : pergilah ke pasar, belilah daging, sayur, kangkung, tomat, rempah-repah dan kembang kol. Namun yang dibeli adiknya, bayam, lengkuas, kunir, sayur, daun salam, bawang merah. Kesalahan pengungkapan (ekspressive errors) : kesalahan yang dilakukan pembicara. Contoh : seorang petugas Bandar udara mengucapkan fifteen, padahal yang dimaksud fifty. Kesalahan perorangan atau disebut errors of individuals yakni kesalahan yang timbul dari seseorang di antara teman-temannya sekelas. Kesalahan kelompok atau disebut errors of groups merupakan kesalahan yang dilakukan sebagian besar siswa. Cara untuk memperbaiki kesalahan itu harus secara kelompok pula dan memerlukan waktu lumayan lama. Latihan bersama bisa menjadi solusi untuk memperbaiki kesalahan kelompok ini.

Kesalahan dalam menganalogi disebut errors of overgeneralization atau analogical errors merupakan kesalahan yang dilakukan seseorang yang belajar bahasa, sudah menguasai suatu bentuk bahasa yang dipelajari kemudian diterapkan dalam bentuk bahasa lain, pada hal bentuk itu tidak dapat diterapkan. Kesalahan 
transfer disebut transfer errors yakni kesalahan yang terjadi apabila kebiasaan pada bahasa pertama diterapkan pada bahasa yang dipelajari. Kesalahan guru yakni kesalahan yang bersumber dari guru. Kesalahan tersebut berhubungan dengan teknik, metode atau materi pengajaran yang dilakukan guru di dalam kelas. Kesalahan lokal disebut local errors yakni kesalahan yang tidak menghambat komunikasi. Artinya, pesan yang diungkapkan dalam kalimat tetap dapat dipahami mitra bicara. Kesalahan global merupakan kesalahan yang disebabkan karena efek dari sebuah makna terhadap seluruh kalimat. Kalimat yang bisa menimbulkan suatu penafsiran maknayang berbeda dengan makna yang dimaksudkan oleh penutur atau pembicaranya.

Dalam hal pembelajaran bahasa ada dua kemungkinan penyebab kesalahan dalam berbahasa. Kemungkinan tersebut antara lain meliputi pembelajar bahasa segera menguasai sebuah bahasa yang diajarkan dan pembelajar tersebut tidak segera menguasai bahasa yang diajarkan. Kesalahan berbahasa yang berasal dari peserta didik penyebabnya antara lain: kemauan, kesungguhan, dan kemampuan peserta didik dalam mempelajari bahasa yang dipelajari. Artinya, peserta didik yang mempunyai kemauan tinggi, maka akan segera menguasai bahasa yang dipelajarinya. Kesungguhan dalam mempelajari bahasa akan berdampak pada kecermatan dan ketekunannya dalam mempelajari bahasanya. Oleh karena itu, peserta didik yang memiliki kesungguhan dan ketekunan tinggi ia segera menguasai bahasa yang dipelajarinya. Sejalan dengan hal tersebut (Pateda, 1989:67) menjelaskan bahwa penyebab kesalahan berbahasa bersumber pada ketidakhatihatian pembelajar bahasa, karena wawasannya tentang bahasa yang dipelajari. Hal itu mengakibatkan terjadinya suatu interferensi.

Penyebab terjadinya kesalahan berbahasa yang berasal dari luar pembelajar bahasa, yang dimaksud ialah lingkungan sekitar pembelajar bahasa, guru yang mendidik pembelajar bahasa, dan bahasa ibu dari pembelajar bahasa. Faktor dari lingkungan sekitar pembelajar bahasa mempunyai peran yang signifikan terhadap pemerolehan dari suatu bahasa atau penguasaan suatu bahasa yang dipelajari. Lingkungan sekitar pembelajar bahasa adalah lingkungan yang dapat memengaruhi pembelajaran bahasa. Lingkungan tersebut antara lain: lingkungan yang berada di rumah, lingkungan yang berada dari luar rumah dan lingkungan yang berada di dalam sekolah.

\section{METODE PENELITIAN}

Pada penelitian ini metode yang digunakan adalah kualitatif. Metode kualitatif adalah suatu prosedur untuk melakukan penelitian yang bertujuan menghasilkan sebuah data bersifat deskriptif. Artinya, data berupa kata-kata yang tertulis maupun secara lisan, berasal dari orang-orang dan suatu perilaku yang bisa untuk diamati (Bogdan dan Taylor dalam Moleong, 2017:4). Penelitian ini termasuk dalam deskriptif kualitatif karena lebih menekankan pada sebuah proses, melakukan sebuah pembahasan dengan fokus, memiliki seperangkat syarat untuk melakukan pemeriksaan terhadap keabsahan data, rancangan penelitian yang sifatnya sementara, dan hasil penelitian disepakati kedua belah pihak, peneliti dan subjek peneliti. Objek yang menjadi kajian dalam penelitian ini adalah status dan komentar di Facebook. Data-data yang menjadi bahan kajian dalam penelitian ini berupa katakata dan kalimat-kalimat pada bagian status dan komentar teman di Facebook. Sumber data berupa sumber data tertulis,yaitu status dan komentar teman di

Tabasa: Jurnal Bahasa, Sastra, dan Pengajarannya

Vol. 1, No. 1, Juni 2020 
Facebook pada tahun 2017 yang diperoleh secara acak dari status dan komentar teman di Facebook.

Pada pengumpulan data, dalam penelitian ini menggunakan metode menyimak dan mencatat. Metode menyimak adalah suatu kegiatan untuk pemerolehan data yang dilakukan dengan cara menyimak suatu penggunaan bahasa (Mahsun, 2005:90). Simak dan catat merupakan suatu proses yang dilakukan dengan cara mencatat data-data. Data-data dalam penelitian ini berupa kata-kata.

Analisis data yang dilakukan menggunakan metode padan intralingual. Metode intraligual adalah suatu metode untuk menganalisis dengan cara menghubungkan beberapa unsur yang memiliki sifat lingual, baik yang ada dalam satu bahasa maupun beberapa bahasa yang berbeda (L. Pilliere 2010-104). Analisis data menjadi suatu upaya yang bertujuan untuk mengklasifikasi dan mengelompokkan data (Mahsun, 2005:253).

Pada penyajian hasil, menggunakan metode informal. Maksudnya, perumusan dengan kata-kata biasa walaupun terminologi dan teknis yang dipakai sama. Datadata yang sudah dianalisis kemudian ditampilkan dengan kata-kata dan hasil akhir disimpulkan, kemudian disusun menjadi sebuah laporan penelitian (Sudaryanto, 1993:145).

Pijakan yang digunakan sebagai dasar untuk mengananalisis data adalah pedoman umum ejaan bahasa Indonesia. Pedoman meliputi penggunaan pada huruf, tata tulis pada kata, dan penggunaan pada tanda baca. Pijakan itu juga sebagai rujukan berbagai implementasi dalam berbahasa Indonesia, terutama bahasa tulis yang sesuai kaidah, termasuk dalam menggunakan media sosial Facebook.

\section{HASIL PENELITIAN DAN PEMBAHASAN Wujud Kesalahan Penggunaan Bahasa Indonesia di Facebook}

Penelitian ini bermaksud mengkaji tentang kesalahan-kesalahan pada ejaan yang terdapat dalam status dan komentar di Facebook. Berikut ini wujud kesalahannya. Bahasa Inggris yang terdapat dalam status dan komentar di Facebook menjadi suatu bentuk kreativitas penulis untuk menciptakan bahasa yang dianggap menarik. Adanya unsur dari bahasa Inggris digunakan dalam bentuk kata, frase, dan kalimat. Sebagian besar penggunaannya bahasa Inggris hanya terdiri satu atau dua kata, namun ada juga dipakai untuk satu kalimat utuh, misalnya pada kalimat $i$ like your status (aku menyukai statusmu). Berikut ini adalah bentuk variasi bahasa Indonesia gaul dan bahasa Inggris pada status dan komentar pada Facebook.

\section{Data1}

\section{Nyabar slingbag yang bisa ready besok. \\ Terima kasih}

Kesalahan yang terdapat pada kalimat di atas yakni kata nyabar bahasa gaul yang sulit untuk di mengerti, bentuk bahasa campuran antara bahasa gaul Indonesia dengan bahasa Inggris (slingbag, ready). Dalam data tersebut terdapat akronim, yakni "Nyabar". Data tersebut menunjukkan bahwa ada proses pemendekan yang menggabungkan kata "Nya" dengan "Bar". Padahal 
sebenaranya kata tersebut sebenarnya adalah Nyari Barang. Kata "Slingbag" berasal dari bahasa Inggris, yang memiliki arti tas selempang. Sedangkan kata dari bahasa Inggris lainnya ialah "ready", yang berarti siap. Berpijak dari hal tersebut dapat diketahui maksud kalimat tersebut adalah sedang mencari barang berupa tas selempang yang bisa digunakan besok. Oleh sebab itu, hendaknya kalimat yang digunakan seharusnya, mencari barang yang bisa digunakan besok. Terima kasih.

Kesalahan lainnya ialah kesalahan saat menggunakan huruf miring pada penulisan kata atau istilah asing. Pada di atas terdapat kata dari bahasa Inggris, yakni slingbag dan ready. Jika menggunakan kata atau istilah dari bahasa asing, maka hendaknya ditulis secara miring. Markhamah (2014:95) menjelaskan bahwa kesalahan dalam penggunaan huruf miring terjadi dalam menuliskan kata atau komponen kalimat yang seharusnya digunakan huruf miring, tetapi digunakan huruf tegak, atau sebaliknya, komponen yang seharusnya digunakan huruf tegak, tetapi digunakan huruf miring.

Beberapa kaidah yang perlu diperhatikan terkait penggunaan huruf miring yang sering dilanggar adalah penggunaan huruf miring untuk menuliskan nama buku, majalah, dan surat kabar, termasuk kini adalah dalam postingan di media sosial. Di samping itu, ditemukan kesalahan pada penggunaan huruf miring yang dipakai untuk menegaskan atau mengkhususkan bagian kata, kata, atau kelompok kata. Misalnya pada data di atas, bisa saja kata Nyari Barang Tas Selempang ditulis dengan huruf miring.

\section{Data 2}

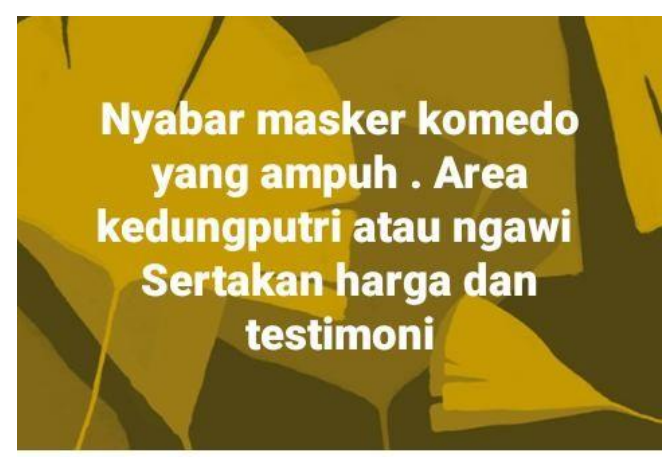

Berdasarkan data tersebut ditemukan kembali akronim, yakni "nyabar". Arti kata tersebut adalah mencari barang. Pada data tersebut juga ditemukan kesalahan pada penulisan "kedungputri atau ngawi", seharusnya apabila mengacu pada PUEBI penulisannya Kedungputri atau Ngawi. Hal tersebut sesuai dengan ketentuan penggunaan pada huruf kapital sebagai huruf pertama nama geografi. Oleh sebab itu, perbaikan yang bisa dilakukan pada kalimat di atas ialah mencari barang masker komedo yang ampuh di area Kedungputri atau Ngawi. Lengkapi dengan harga dan testimoninya.

Markhamah (2014:87) mengungkapkan bahwa kaidah-kaidah yang harus diperhatikan terkait penggunaan huruf kapital adalah sebagai berikut. Kesalahan yang terjadi saat menggunakan huruf kapital pada awal kalimat; kesalahan penggunaan huruf kapital dalam penggunaannya sebagai huruf pertama ungkapan yang berkaitan dengan hal-hal keagamaan, kitab suci, dan nama Tuhan; kesalahan penggunaan huruf kapital sebagai huruf yang posisinya pertama untuk nama gelar, kehormatan, keturunan, yang diikuti nama orang; kesalahan penggunaan huruf kapital pada penulisan bagian nama seperti van, der, da, de, di, bin, dan ibnu. Kata-kata tersebut

Tabasa: Jurnal Bahasa, Sastra, dan Pengajarannya

Vol. 1, No. 1, Juni 2020 
ditulis menggunakan huruf kecil, kecuali kata-kata tersebut letaknya di awal kalimat; kesalahan dalam menggunakan huruf besar sebagai huruf pertama untuk nama suatu bangsa, suku, dan bahasa; kesalahan penggunaan huruf kapital pada penulisan nama tahun, bulan, hari, hari raya, dan peristiwa sejarah; kesalahan penggunaan huruf besar sebagai huruf pertama nama geografi; kesalahan penggunaan huruf kapital sebagai huruf pertama nama resmi badan, lembaga pemerintah, dan ketatanegaraan serta nama dokumen resmi; kesalahan penggunaan huruf kapital pada nama-nama buku dan sejenisnya; kesalahan penggunaan huruf kapital pada penulisan nama singkatan nama, gelar, dan sapaan; kesalahan penggunaan huruf kapital yang terletak sebagai huruf pertama dalam hubungan sebuah kekerabatan.

\section{Data 3}

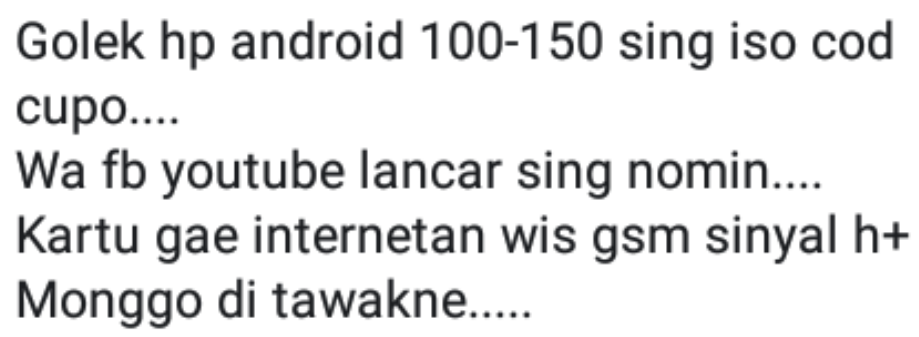

Dari kalimat diatas banyak terdapat kesalahan berbahasa sehingga membuat para pembaca susah untuk memahami. Kesalahan berbahasa tersebut dapat dilihat dengan penggunaan bahasa yang bercampur antara bahasa Jawa, Inggris, dan singkatan-singkatan yang tidak semua orang dapat dengan mudah mengerti. Sebaiknya, kalimat bisa diperbaiki menjadi, mencari handphoneandroid hargaRp.100.000 s/d Rp.150.000 yang bias bertemu secara langsung di Cupo. Handphone Android yang dicari harus ada aplikasi whatapps, facabook, youtube lancer yang tidak ada kelemahan. Kartunya bias digunakan untuk internetan, sudah GSM sinyal 3G. Silakan ditawarkan.

\section{Data 4}

\section{Serba serbi kampus, dengan sejuata kebahagian .. seve nanti kalau kita udah wisuda jadi kenangan berharga....cayoo.. all.. cemangat|}

Pada data di atas dapat diketahui sebuah penggunaan bahasa Indonesia yakni bahasa gaul, bahasa Inggris, dan bahasa Mandarin yang penulisannya dicampur, apabila dicermati terdapat banyak kesalahan berbahasa. Ke s a Ia ha $\mathrm{n}$ ditemukan adalah kata "Cayoo"," cemangat", "sejuata", dan penggunaan kata bahasa Inggris all,save. Perbaikan kalimat yang bisa dilakukan yakni, serbaserbi kampus dengan sejuta kebahagiaan. Disimpan nanti kalau kita sudah wisuda untuk menjadi kenangan yang berharga. Semangat semuanya.

Adanya unsur yang berasal dari bahasa Mandarin dipadukan dengan bahasa Indonesia gaul. Bahasa Mandarin yang digunakan hanya sebagai sebuah pelengkap, sebab hanya terdiri dari satu kata. Pemakaian kata cayoo (jiayou) 
adalah satu-satunya bahasa Mandarin terdapat dalam status dan komentar di Facebook. Jia you merupakan ungkapan yang berasal dari bahasa Mandarin,jia bias diartikan memperbesar,memperbanyak; tambah, menjumlah; menambah, melebih-lebihkan; menambah, membubuhkan. Sedangkan you mempunyai arti meminyaki, mengisi bahan bakar, mencurahkan tenaga (Suharto, 2002:312-313). Bila digabungkan, arti yang tepat digunakan menjadi memperbesar mencurahkan tenaga. Menambah untuk mengisi bahan bakar juga biasa digunakan,namun masih dalam bentuk lugas. Berdasarkan arti yang sebenarnya, maka gabungan dari kata tersebut berarti sebuah ungkapan untuk memberikan sebuah semangat dan motivasi yang ditujukan pada orang lain.

\section{Data 5}

\section{Hai fb}

Pada data yang ditemukan di atas, terdapat kata singkatan yaitu“fb", yang tentu saja kepanjangan dari facebook. Bagi yang sudah akrab dengan aplikasi tersebut tentu itu bukan hal yang baru. Namun, bagi yang belum tahu tentang aplikasi tersebut pasti bingung. Oleh sebab itu, perbaikan yang bisa dilakukan yakni "Hai fb" . Bentuk tulisan pada status dan komentar di facebook tidak lepas dari bentuk berbagai variasi kata yang ditunjukkan dengan adanya sebuah penyingkatan kata. Penelitian yang sama telah dilakukan Astuti (2002) berjudul "Analisis Penggunaan Singkatan dalam Wacana Short Message Servicedi handphone".

Hasil penelitiannya memperlihatkan bahwa bentuk-bentuk tulisan singkat dalam pesan singkat dibagi menjadi enam, yaitu: singkatan untuk nama, untuk orang, untuk gelar, untuk sapaan, untuk jabatan, dan pangkat; singkatan pesan singkat yang terdiri dari satu huruf; singkatan pesan singkat yang terdiri dari dua huruf; singkatan pesan singkat dalam suku kata; singkatan pesan singkat yang terdiri tiga huruf; singkatan pesan singkat yang terdiri empat huruf.

\section{Data 6}

\section{Tolong yang tau ortu anak ini . Mungkin ada yang kenal.}

Pada data di atas terdapat akronim yaitu ortu. Akronim itu merupakan gabungan dari kata "orang" dan "tua". Selain itu, terdapat kata yang tidak baku yakni "tau". Kesalahan yang lain ialah tidak adanya tanda tanya diakhir kalimat. Melihat dari kalimat di kalimat di atas hendaknya diberikan tanda tanya sehingga menjadi, tolong yang mengetahui orang tua anak ini. Mungkin ada yang mengenalnya?. Alternatif lainnya ialah merubah susunan kalimat seperti berikut ini, tolongbagi yang mengetahui atau mengenal orang tua anak ini.

\section{Data 7}

\section{bisa tolong bantu cek in resi ini gk man teman...soal ny tk cek gk bisa,krim udh dri hri sabtu...}


Dari data di atas banyak terdapat kesalahan berbahasa pada penyusunan kalimat. Terdapat kata-kata yang disingkat dan akronim yang belum mengikuti ketentuan yang terdapat dalam Pedoman Umum Ejaan Bahasa Indonesia. kata-kata tersebut antara lain: gk, man, ny, krim, dri, hri. Adapun perbaikan yang bisa dilakuan yakni tolong bantu mengecek resi saya teman-teman. Sudah dari hari Sabtu saya mengecek tidak bisa.

Kesalahan yang lainnya ialah saat menggunakan huruf kapital dan tanda titik. Huruf kapital dipakai sebagai huruf pertama awal kalimat. Kata "bisa" seharusnya tertulis "Bisa". Sebaiknya titik yang digunakan dalam kalimat itu masing-masing cukup satu saja.

\section{Data 8}

\section{Yg minat kerang sungai nya \\ Monggo order dr skarg! Kirim nnti siang.. $\mathrm{Cm} \mathrm{5.000/kg}$}

\section{Fast respon Wa \\ 085804508400}

Berpijak dari data tersebut, dapat ditemukan bahwa awal kalimat tidak menggunakan huruf besar dan singakatannya tidak tepat. Sebaiknya "Yang" jangan diawal kalimat. Kesalahan selanjutnya ialah penulisan "sungai nya" diperbaiki menjadi "sungainya". Kata "Order" baiknya diganti dipesan. Singkatan "dr" diganti "dari", "skrag" diganti "sekarang" tak usah menggunakan tanda seru. Kata "nnti" diganti "nanti". Titik setelah kata "siang" cukup satu saja. "Cm" diganti "Cuma", "5.000/kg" diganti "Rp. 5.000, 00 per kilogram. "Fast respon Wa" diganti "Respon cepat melalui WhatsAps". Oleh sebab itu, sebaiknya kalimat di atas dapat diperbaiki menjadi, bagi yang berminat kerang sungai. Silakan dipesan dari sekarang. Nanti siang dikirim. Cuma Rp. 5.000.,00 per kilogram. Respon cepat melalui WhatsApss Nomornya 085804508400.

\section{PENUTUP}

Berdasarkan dari hasil dan pembahasan dapat diketahui simpulan dalam penelitian ini yakni terdapat kesalahan berbahasa Indonesia ejaan dalam status dan komentar di facebook antara lain: berupa variasi dari bahasa gaul yang terdiri dari : bahasa Indonesia gaul yang bercampur dengan bahasa Inggris; bahasa Indonesia gaul, bahasa Inggris, dan bahasa Jawa; bahasa Indonesia gaul, bahasa Inggris dan bahasa Mandarin; bentuk-bentuk dari singkatan bervariasi, baik berwujud sebuah kata maupun sebuah frasa. Bentuk-bentuk dari singkatan yang terdapat dalam status dan komentar di Facebook terbagi menjadi empat jenis singkatan yaitu singkatan satu huruf;singkatan yang terdiri atas dua huruf; singkatan yang terdiri atas tiga huruf; singkatan empat huruf. Bentuk dari singkatan kata tersebut ditulis dalam bentuk huruf, tanda baca, angka, maupun perpaduannya. Kesalahan ejaan yang terdapat dalam status dan komentar di Facebook yang lainnya yakni kesalahan yang ada dalam penulisan huruf kapital dan kesalahan penggunaan tanda baca. Kesalahan dalam penggunaan tanda baca terdiri dari kesalahan tanda titik, kesalahan tanda koma, kesalahan tanda tanya, kesalahan tanda seru, kesalahan dalam menggunakan tanda petik.. 


\section{DAFTAR PUSTAKA}

Andayani. (2015). Problema dan Aksima dalam Metodologi Pembelajaran Bahasa Indonesia. Yogyakarta: Deepublish.

Alwi, Hasan, dkk. (ed.). 2007. Kamus Besar Bahasa Indonesia Edisi Ketiga. Jakarta: Balai Pustaka.

Astuti,HandayaniDwiPuspa.(2002). "AnalisisPenggunaan Singkatan dalam Wacana Short Messange Service di Handphone". Skripsi S1. Surakarta:Universitas Muhammadiyah Surakarta.

Mahsun,M.S.(2005). Metode Penelitian Bahasa: Tahapan Strategi, Metode, dan Tekniknya. Jakarta:PT.RajaGrafindo Persada.

Markhamah dan Sabardila, A. (2014). Analisis Kesalahan Berbahasa dan Karakteristik Bentuk Pasif. Surakarta: UMS Press.

Moleong, Lexy J. (2017). Metode Penelitian Kualitatif. Bandung: Rosdakarya.

Suharto,Y.B.(2002).Kamus Popular Mandarin-Indonesia. Jakarta :Gramedia Pustaka Utama.

Sudaryanto.(1993). Metode dan Aneka Teknik Analisis Bahasa: Pengantar Penelitian Wacana Secara Linguis. Yogyakarta:Duta Wacana.

Pateda, Mansoer (1989). Analisis Kesalahan. Ende Flores: Nusa Indah.

Pilliere,L.(2010). Conflicting voice:An Analys of intralingual translation from brithis to American English.URLhttp://erea.revues.org/1404

Pertiwi, Kusuma. W. (2020). Penetrasi Internet di Indonesia Capai 64 Persen. http://amp-kompas-com.cdn.ampproject.org

Pusat Bahasa Departement Pendidikan Nasional.(2007). Kamus Besar Bahasa Indonesia edisi ketiga. Jakarta Balai Pustaka.

Putrayasa,I.B.(2007).Kalimat Efektif (Diksi,Struktur,dan Logika). Bandung: Refika aditama.

Keraf.G.(1996).Diksi dan Gaya Bahasa. Jakarta:Gramedia.

Kridalaksana,H . (2001). Kamus linguistik.Jakarta:Gramedia Pustaka Utama. 
Analisis Kesalahan Berbahasa Indonesia... | 109 